\title{
ADVERSE EFFECT OF MOBILE PHONE ON TP53, BRCAI GENES AND DNA FRAGMENTATION IN ALBINO RAT LIVER
}

\author{
GOUDA E.M.*, GALAL M.K. AND ABDALAZIZ S.A. \\ Biochemistry Department, Faculty of Veterinary Medicine, Cairo University, 12211 Giza, Egypt. \\ ${ }^{*}$ Corresponding Author: Email- emanmgouda@hotmail.com
}

Received: October 01, 2013; Accepted: November 05, 2013

\begin{abstract}
Although mobile phones among daily indispensable wireless accessories a big concern about their emitted electromagnetic radiation (EMR) hazard. The present study investigated the possible damage induced by their EMR strength and duration on mammalian genome, using male Albino rats as an animal model. Animals were exposed to mobile phone emitted radiation of $1800 \mathrm{MHz}$ frequency for a period of 2 hours. Exposure was performed either continuously or intermittent manners for 3 different exposure periods. The possible mutation in BRCAl and TP53 tumor suppressor genes were studied, and the degree of genomic DNA fragmentation was followed. The obtained results revealed that longer period (six weeks) of continuous EMR exposure induced mutation in both studied genes with relative increase in DNA fragmentation when compared with intermittent exposure. The study warrants the public against excessive exposure to mobile phone-induced EMR. Minimization of such exposure has to safeguard against genetic DNA fragmentation with possible consequent mutation and cancer formation. Keywords- EMR, mobile phone, BRCA1, TP53
\end{abstract}

Citation: Gouda E.M., Galal M.K. and Abdalaziz S.A. (2013) Adverse Effect of Mobile Phone on TP53, BRCAl Genes and DNA Fragmentation in Albino Rat Liver. International Journal of Genomics and Proteomics, ISSN: 0976-4887 \& E-ISSN: 0976-4895, Volume 4, Issue 1, pp.-84-88.

Copyright: Copyright@2013 Gouda E.M., et al. This is an open-access article distributed under the terms of the Creative Commons Attribution License, which permits unrestricted use, distribution and reproduction in any medium, provided the original author and source are credited.

\section{Introduction}

The use of mobile phones is one of the fastest growing technological developments in present days. Globally, they estimated about 5.9 billion mobile phone subscriptions at the end of 2011 [1]. Unfortunately, epidemiological and experimental studies revealed that their emitted EMR at different frequency range can induce various biological alterations. It is recently accused to be the cause of several biological alterations as increasing blood-brain barrier permeability [2], gene expression alteration [3], oxidative DNA damage [4], infertility $[5,6]$ fetal loss and developmental malformations [7]. The altered gene expression has to negatively inflict cellular structural and its functional activity with increased tendency to tumor formation [8]. The EMR is recently classified as "possibly carcinogenic to humans" (Group 2B) as indicated by International Agency for Research on Cancer (IARC) [9]. The capacity for malignant growth is acquired by the stepwise accumulation of defects in specific genes regulating cell growth and tissue homeostasis. Many studies suggested that exposure to EMR was associated with a small but significant increase in the risk of cancer $[9,10]$, which could be induced from gene mutations that resulted from DNA damage [11]. The carcinogenic process has three stages: initiation, promotion and progression. Tumor initiation begins with cellular DNA damage. If this damage is not fixed it can lead to genetic mutations, its repair was occurred mostly through the tumor suppressor genes [12,13]. They are protective genes that normally limit the tumor growth [14].
BRCA1 and TP53 are two examples of these genes. The term P53 originally referred to a 53-kD phosphoprotein. Its gene was located on chromosome 17p [15]. The P53 plays a crucial role in cell cycle regulation and development of apoptosis after DNA damage. Moreover, its role in tumorigenesis was previously reported in solid and hematologic malignancies [16]. Since the TP53 is mutated in more than $50 \%$ of human cancers, it has attracted the interest of several researchers. TP53 mutations can lead either to loss or change of P53 binding activity to its downstream targets and may thus induce aberrant cell proliferation [17]. The breast cancer associated gene1 (BRCA1) contains 24 exons that encode a large protein of 1812 amino acids in mice [18]; it acts as a negative regulator for tumor growth. Different types of mutation have been found in the BRCA1 gene which predisposed to development of cancer [19]. Its mutation causes defective DNA damage repair, cell cycle arrest, increased apoptosis and genetic instability [20]. After DNA damage, through exposure to ionizing radiation, ultraviolet irradiation, the protein expression of BRCA1 is down regulated in TP53 wild type cells. In contrast, protein expression of BRCA1 is stabilized or up regulated after DNA damage in both human and mouse TP53 deficient cells, suggesting that TP53 interact with BRCA1 [21]. Furthermore, BRCA1 requires the presence of P53 for the enhancement of transcriptional activation [22]. The present study was performed to examine the effect of continuous and discontinuous exposure of mobile phone on DNA damage and BRCA1 and TP53 genetic alterations. 


\section{Material and Methods}

\section{Animals}

The current study was carried out on 135 of males' albino rats; weighing 100-120 gm. Rats were reared in Biochemistry and Chemistry of Nutrition Department Faculty of Veterinary Medicine, Cairo University. Basing on the exposure to the EMR, the animals were divided into three main groups of equal rat number $(n=45)$; the first group served as a sham exposed group where the animals were exposed to a mobile phone without battery. The second group (continuous group) exposed daily to EMR from mobile phone for two hrs. and the third group (discontinues group) exposed to EMR for 2 discontinues hours per day (30 minutes exposed interval). The three groups were divided on three experimental periods (two weeks, 4weeks and six weeks) each period composed of (sham $(n=15)$, continuous $(n=15)$ and discontinuous group $(n=15))$. The animals were housed separately in plastic cages under controlled condition of temperature and light in accordance with the Guide for the Care and Use of Laboratory Animals [23]. They were provided with standard food pallets and water adlibitum. The decapitation was proceeding for all rats $(n=45)$ at the end of each period.

\section{Exposure Technique}

The rats were exposed to $1800 \mathrm{MHz}$ of EMR emitted from a mobile phone (Nokia 6600) measured with TRI- filed meter (www.trifieldmeter.com) with specific absorption rate $=0.33 \mathrm{~W} / \mathrm{kg}$. The cell phone was kept on ringing position and placed $0.5 \mathrm{~cm}$ underneath the cage. In the discontinuous group, rats were exposed to EMR from mobile phone in ringing position for 30 minutes and phone without battery for 30 minutes. The sham group was kept in similar cages for the same period in a separate room. The animals were free to move in the cage during the exposure period.

\section{Sampling}

At the end of each experimental period, all rats were anesthetized, decapitated and livers were removed immediately for further analysis.

\section{Genomic DNA Extraction}

Genomic DNA was extracted from liver according to Parborell, et al [24] using the salting out method. The yield and purity of isolated DNA were estimated spectrophotometrically at $260 \mathrm{~nm}$ and $280 \mathrm{~nm}$.

\section{Mutation Analysis for BRCA1 Gene using PCR Single Strand Conformational Polymorphism (PCR-SSCP)}

Rat BRCA1 intron 6 was amplified by PCR using specific primers as follows, forward primer: 5- GCCCTGGCTGTTATCAAA-3 and reverse one: 5-TGCTGCCTAAGGATAATG-3 [25]. PCR was carried out in a total volume of $25 \mu$ containing: $5 X$ PCR Taq Master/ high yield (Jena Bioscience, Germany), 1X BSA, 25 pmol of each primer and $200 \mathrm{ng}$ of genomic DNA. Amplification was carried out in an automated thermal cycler (Bico, Germany) for 35 cycles of denaturation for $60 \mathrm{sec}$. at $95^{\circ} \mathrm{C}$, annealing for $60 \mathrm{sec}$. at $52^{\circ} \mathrm{C}$, and extension for $60 \mathrm{sec}$. at $72^{\circ} \mathrm{C}$, with initial denaturation at $95^{\circ} \mathrm{C}$ for $5 \mathrm{~min}$ and final extension for $10 \mathrm{~min}$ at $72^{\circ} \mathrm{C}$.

SSCP analysis for point mutation was performed according to Yassaee, et al [26] under the following conditions: a mixture of $10 \mu$ PCR product and $10 \mu$ loading buffer was denatured for 10 minutes at $98^{\circ} \mathrm{C}$, rapidly cooled on ice for 20 minutes and separated on a $15 \%$ non-denaturing polyacrylamide gel in 1 X TBE buffer for 4-5 hrs. at $100 \mathrm{~V}$. Bands were then visualized using ethidium bromide staining.

\section{TP53 Gene Mutation Analysis using PCR-SSCP}

The genomic DNA was amplified using PCR for identification of the mutation of the rat TP53 gene in exon 7 according to Gouda, et al [27]. We are using the forward primer 5'-GTG GTA CCG TAT GAG CCA CC-3' and the reverse one 5'-CAA CCT GGC ACA CAG CTT CC-3'. The PCR mixture contained 5X PCR Taq Master/ high yield (Jena Bioscience, Germany), $0.5 \mu$ l of each primer, $1 \mu$ of BSA, $1 \mu$ l of DNA, and sterilized distilled water to make a final volume of 25 $\mu$ l. The PCR reaction was included pre-denaturation for 5 minutes at $95^{\circ} \mathrm{C}$ followed by 35 cycles $95^{\circ} \mathrm{C}$ for $1 \mathrm{~min}, 59^{\circ} \mathrm{C}$ for $1 \mathrm{~min}, 72^{\circ} \mathrm{C}$ for 1 minutes and a final extension of 10 minutes at $72^{\circ} \mathrm{C}$. The mutation detection for TP53 was performed using SSCP technique. A total of $10 \mu \mathrm{L}$ PCR product was mixed with $10 \mu \mathrm{L}$ of the denaturation solution $(0.1 \%$ bromophenol blue, $0.1 \%$ xylene cyanole in formamide). The mixture was denatured for 10 minutes at $98^{\circ} \mathrm{C}$, rapidly chilled on ice for 20 minutes. The samples were then electrophoresed in 15\% PAGE at $150 \mathrm{~V}$ for 5 minutes, subsequently at $80 \mathrm{~V}$ at room temperaturen. The gel was stained with ethidium bromide $(0.5 \mu \mathrm{g} / \mathrm{ml})$ and visualized under a UV transilluminator, the picture was taken using a digital camera.

\section{Genomic DNA Fragmentation}

In fragmentation assay, DNA concentration was determined calorimetrically by diphenylamine assay as previously described by Diab, et al [28]. Liver samples were lysed in hypotonic lysis buffer pH 8.0. Lysates were centrifuged at $13000 \mathrm{Xg}$ for $10 \mathrm{~min}$. The supernatant containing small DNA fragments was separated from the pellet of intact DNA, and divided into 2 portions one for electrophoretic analysis using agarose gel electrophoresis. The second portion and pellet were precipitated with TCA and then were centrifuged. After centrifugation the supernatant were resuspended in 2 volumes of diphenylamine solution. Samples were store at $4^{\circ} \mathrm{C}$ for $48 \mathrm{~h}$ and measured spectrophotometry at $578 \mathrm{~nm}$. DNA fragmentation was expressed as percentage of total DNA appearing in the supernatant fractions.

\section{Statistical Analysis}

DNA fragmentation values were listed as the mean \pm S.D. The observed difference between different means in the three groups was statistically analyzed by ANOVA test. The observed difference among means by SSCP technique was statistically evaluated the using Fisher's exact test at $p<0.05$ and the analysis were performed by SPSS 16.0 software package (SPSS Inc., Chicago, IL, USA).

\section{Results}

PCR-SSCP Analysis of BRCA1 Gene Mutation in Liver Induced by Mobile Phone Exposure in Rats

Table 1- Frequency of BRCA1 gene mutation detected after exposure to EMR

\begin{tabular}{|c|c|c|c|c|c|c|c|}
\hline \multirow{2}{*}{$\begin{array}{l}\text { Duration of } \\
\text { exposure }\end{array}$} & \multicolumn{2}{|c|}{ Sham group } & \multicolumn{2}{|c|}{$\begin{array}{l}2 \text { hrs. Continuous } \\
\text { group }\end{array}$} & \multicolumn{2}{|c|}{$\begin{array}{c}2 \text { hrs. Discontinuous } \\
\text { group }\end{array}$} & \multirow[t]{2}{*}{$p$ value } \\
\hline & Number & $\%(\mathrm{M})$ & Number & $\%(\mathrm{M})$ & Number & $\%(\mathrm{M})$ & \\
\hline 2 weeks & $15(0)$ & 0 & $15(0)$ & 0 & $15(0)$ & 0 & $1.00^{\mathrm{ND}}$ \\
\hline 4 weeks & $15(0)$ & 0 & $15(3)$ & 20 & $15(3)$ & 20 & $1.00^{\mathrm{ND}}$ \\
\hline 6 weeks & $15(0)$ & 0 & $15(5)$ & 33.3 & $15(3)$ & 20 & $0.05^{*}$ \\
\hline \multicolumn{8}{|c|}{$\begin{array}{l}M=\text { mutant } \%, N D=\text { insignificant, } 15=\text { total number of rats, (---) number of mutant } \\
\text { rat } \\
\text { "mean there is a significant difference in the frequency of percentage of mutation } \\
\text { between the different groups using the Fisher's exact test. The most prominent } \\
\text { frequency was recorded in the continuously exposed rats for } 6 \text { weeks } 33.3 \% \text {. }\end{array}$} \\
\hline
\end{tabular}




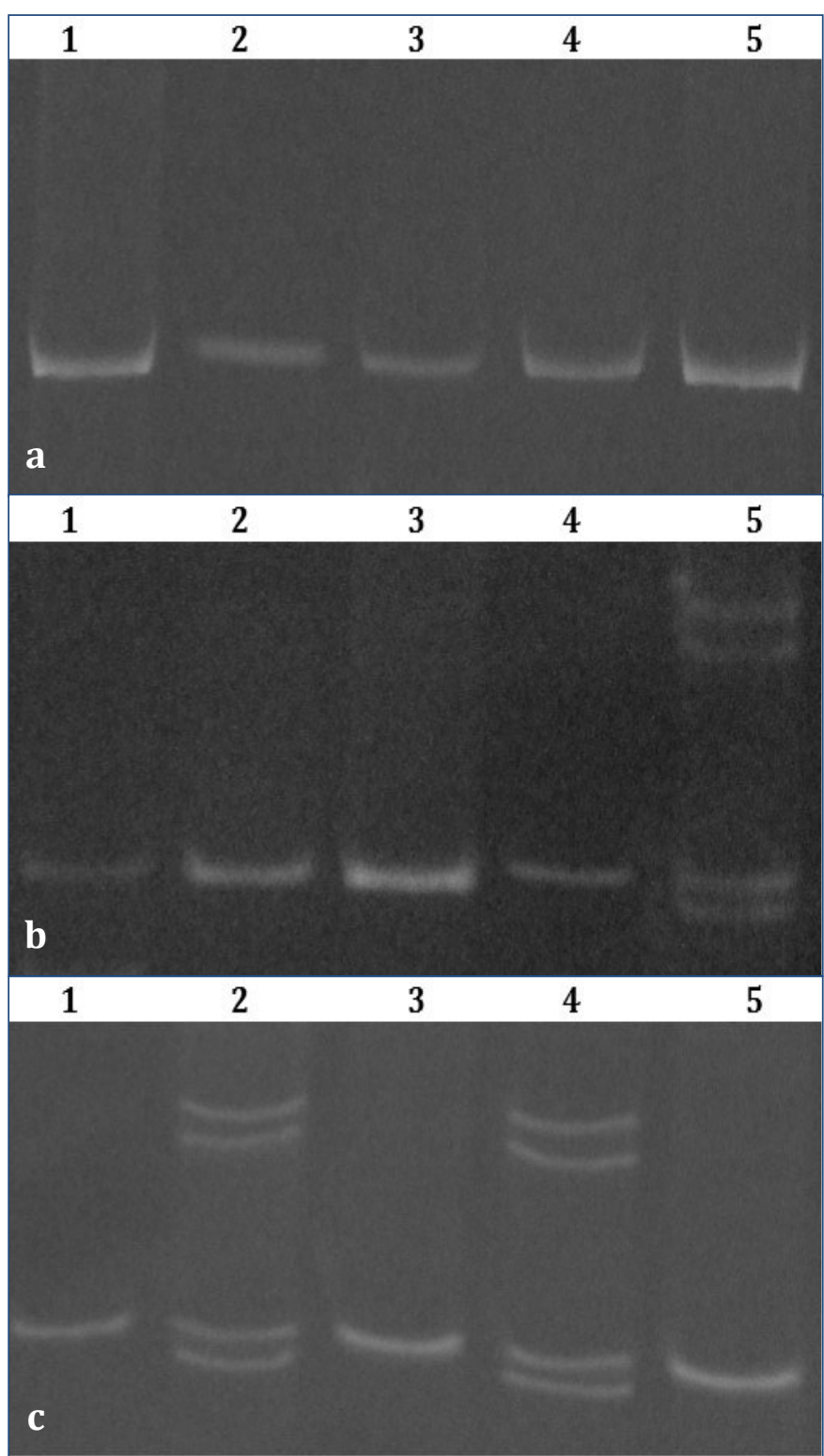

Fig. 1- Representative Results of PCR-SSCP Analysis of BRCA1 Gene Mutation in Liver Induced by Mobile Phone Exposure in Rats 1(a)- Lanes 1 \& 2: sham group, Lanes $3 \&$ 4: 2 hrs. discontinuous exposure, Lane 5: 2 hrs. continuous exposure; 1 (b)- Lanes $1 \& 2$ : sham group, Lane 3: 2 hrs. discontinuous exposure, Lanes 4 \& 5: 2 hrs. continuous exposure; 1(c)- Lanes 1: sham, Lanes $2 \& 3$ : 2 hrs. discontinuous exposure, Lanes $4 \& 5: 2$ hrs. continuous exposure.

The band pattern reveals whether a mutation exists (Lanes 5 (1b), 2 \& 4 (1c)) with heterozygous wild/mutant; while the other lanes have no mutation.

[Table-1] and [Fig-1] showing the mutation effects of mobile phone exposure on BRCA1 in Rats, [Fig-1](a), [Fig-1](b), [Fig-1](c) are showing the PCR-SSCP analysis results after 2, 4 and 6 weeks exposure respectively.

\section{SSCP Analysis of Amplified PCR Products of TP53 Gene Ex-} on7

[Fig-2] and [Table-2] showing SSCP Analysis of Amplified PCR Products of TP53 Gene Exon7, [Fig-2](a) showing 2 \& 4 weeks exposure while [Fig-2](b) showing 6 weeks exposure.

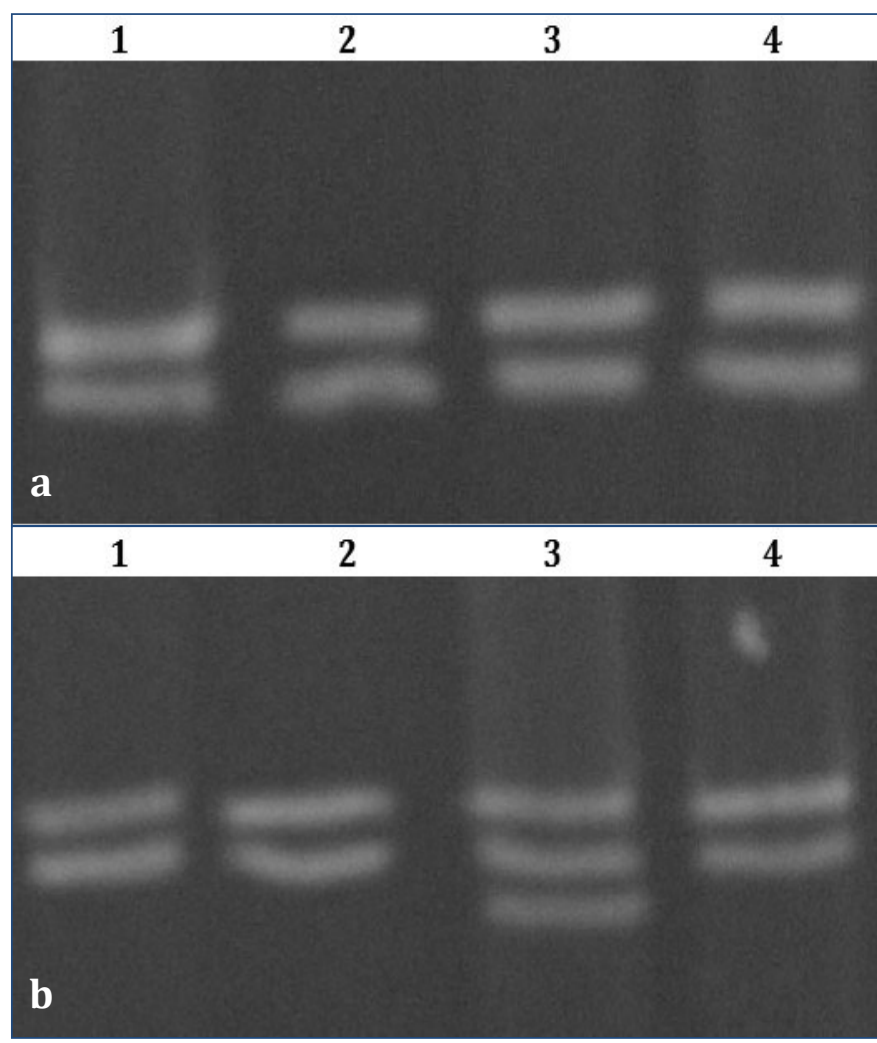

Fig. 2- Representative results of SSCP Analysis of Amplified PCR Products of TP53 Gene Exon7

(2a)- Lane 1: sham, Lanes 2 \& 3: 2 hrs. continuous group, Lane 4: 2 hrs. discontinuous group; (2b)- Lane 1: sham, Lanes $2 \& 3$ : 2 hrs. continuous group, Lane 4: 2 hrs. discontinuous group

The band pattern reveals whether a mutation exists (Lane $3(2 b)$ ) with heterozygous wild/mutant; other lanes had no mutation.

Table 2- Summary of incidences of TP53 gene mutation after exposure to EMR

\begin{tabular}{|c|c|c|c|c|c|c|c|}
\hline \multirow{2}{*}{$\begin{array}{l}\text { Duration of } \\
\text { exposure }\end{array}$} & \multicolumn{2}{|c|}{ Sham group } & \multicolumn{2}{|c|}{$\begin{array}{l}2 \mathrm{hrs} \text {. Continuous } \\
\text { group }\end{array}$} & \multicolumn{2}{|c|}{$\begin{array}{c}2 \text { hrs. Discontinuous } \\
\text { group }\end{array}$} & \multirow[t]{2}{*}{$p$ value } \\
\hline & Number & $\%(\mathrm{M})$ & Number & $\%(M)$ & Number & $\%(\mathrm{M})$ & \\
\hline weeks & $15(0)$ & 0 & $15(0)$ & 0 & $15(0)$ & 0 & $1.00^{\mathrm{ND}}$ \\
\hline & 15( & 0 & & 20 & & 0 & $1.00^{\mathrm{ND}}$ \\
\hline & $15(0)$ & 0 & $15(5)$ & 33.3 & $15(0)$ & 0 & $0.00737^{*}$ \\
\hline \multicolumn{8}{|c|}{$\begin{array}{l}M=\text { mutant } \%, N D=\text { insignificant, } 15=\text { total number of rats, (---) number of mutant } \\
\text { rat } \\
{ }^{*} \text { mean there is a significant difference in the frequency of percentage of mutation } \\
\text { between the different groups using the Fisher's exact test. The most frequent one } \\
\text { appeared in } 2 \text { hrs continuous group after } 6 \text { weeks }(33.3 \%) \text {. }\end{array}$} \\
\hline
\end{tabular}

DNA Fragmentation Induced in Hepatic Tissue after EMR Exposure

[Fig-3] and [Table-3] showing DNA fragmentation induced in hepatic tissue after continuous and discontinuous mobile phone EMR exposure, [Fig-3](a), [Fig-3](b), [Fig-3](c) are showing the hepatic tissue DNA Fragmentation after 2, 4 and 6 weeks exposure respectively.

Electrophoresis of supernatant DNA fragments shows the increased rate of DNA fragmentation in rats exposed to either continuous or discontinuous mobile phone EMR in comparison to sham control group. The most prominent effect was recorded in the continuously exposed rats for 6 weeks. 


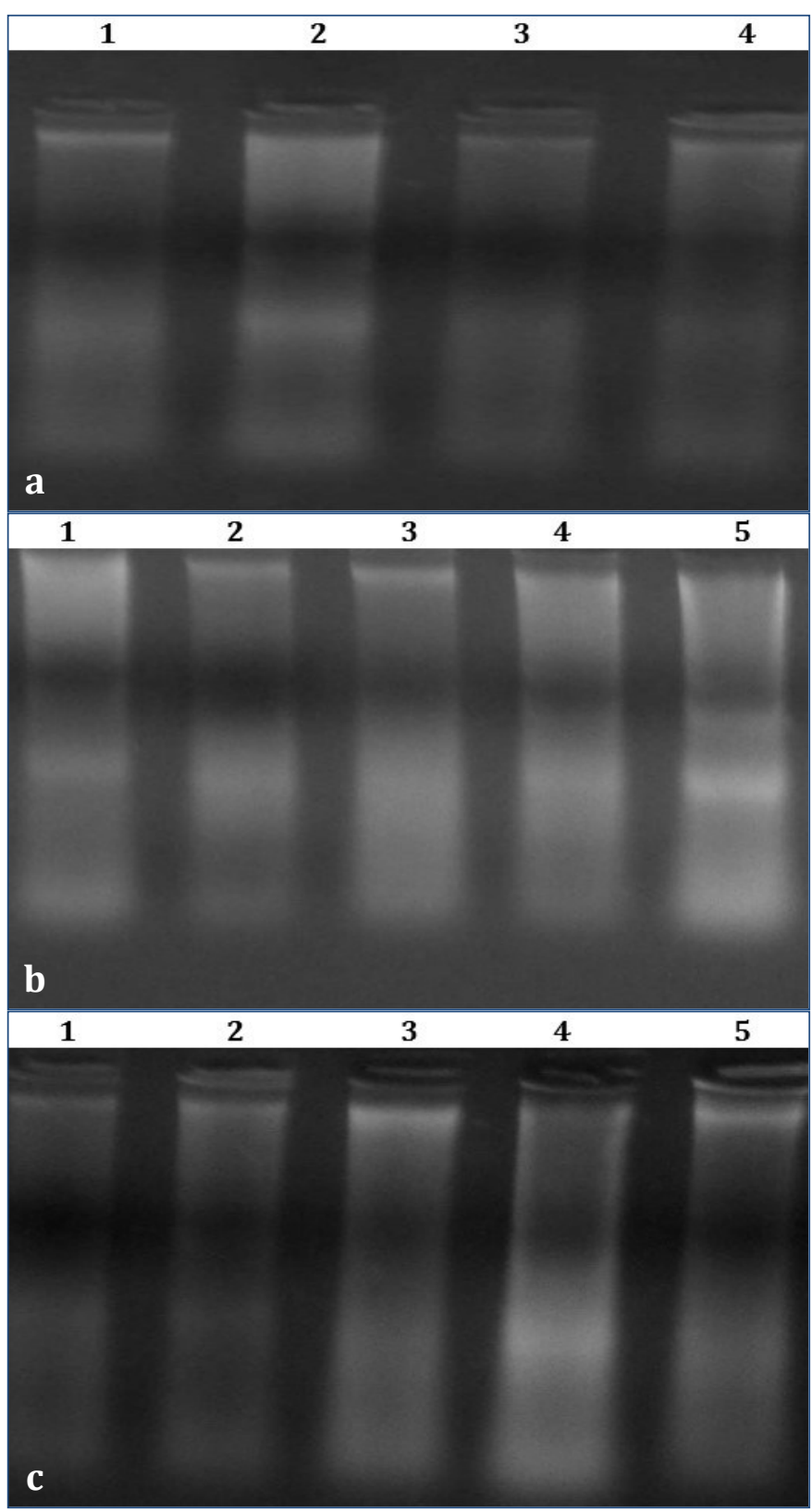

Fig. 3- Representative results of DNA Fragmentation Induced in Hepatic Tissue after EMR Exposure

(3a)- Lane 1: sham, Lanes 2 \& 3: 2 hrs. continuous exposure, Lane 4: 2 hrs. discontinuous group; (3b)- Lane 1: sham, Lanes 2 \& 3: 2 hrs. discontinuous exposure, Lane 4, 5: 2 hrs. continuous group; (3c)- Lane 1: sham, Lanes 2, 3: 2 hrs. discontinuous exposure, Lane 4, 5: 2 hrs. continuous group.

Table 3- Effects of continuous and discontinuous exposure of mobile phone EMR on the percentage of genomic DNA fragmentation

\begin{tabular}{|c|c|c|c|}
\hline \multirow{2}{*}{ Duration of exposure } & \multicolumn{3}{|c|}{ Groups } \\
\hline & Sham & 2 hrs. continuous & 2 hrs. Discontinuous \\
\hline 2 weeks & $27.09 \pm 1.54 \mathrm{~A}^{*}$ & $31.32 \pm 1.23^{B} b^{*}$ & $30.4 \pm 0.64 \mathrm{C}$ \\
\hline 4 weeks & $29.1 \pm 7.7$ & $36.11 \pm 3.65^{b}$ & $31.286 \pm 1.73$ \\
\hline 6 weeks & $30.06 \pm 2.53 \mathrm{~A}^{*}$ & $39.26 \pm 1.138^{B b^{*}}$ & $33.27 \pm 2.82^{C^{*}}$ \\
\hline
\end{tabular}

\section{Discussion}

Depending on many factors including duration of exposure to EMR, distance from the various sources, species, tissues as well as the conditions of exposure variable biological effects were reported [29]. The use of heavy cell phone doubles the risk of getting brain cancers in adult users that use the cell phone on the side of the head. This risk is five-times increased in younger people [30]. Experimental data obtained from our study indicated that $1800 \mathrm{MHz}$ of EMR exposure for 6 weeks (2 hrs. /day) resulted in mutation in BRCA1 and TP53 genes [Table-1] and [Table-2]. The percentage of mutation in BRCA1 gene was increased with prolonged continuous exposure [Table-1]. The exposure to EMR had several cytogenetic effects (effect on chromosomes, DNA fragmentation, and gene mutations). Lopez-Martin, et al [31] found that EMR caused different effects on c-Fos gene expression in the rat brain, Nylund \& Leszezynski [32] showed that gene and protein expression were altered, in two variants of human endothelial cell line, in response to one hour mobile phone radiation exposure. Karien, et al [33] showed that the EMR alters protein expression in human endothelial cell line. On the other hand, Hung, et al [34] reported that EMR exposure did not produce significant changes in cell numbers, cell cycle distribution, or level of DNA damage or global gene expression. The mutation in BRCAl gene leads to multiple genetic alterations including the inactivation of TP53 gene and activation of a number of oncogenes as reported by Somasundaram [35]. Whereas mutations in TP53 seem to occur at a very high frequency in BRCAI mutation, suggesting that P53 might be an important checkpoint for BRCAl associated tumorigenesis [36]. As shown from the data, the percentage and the level of genomic DNA fragmentation increased in rats exposed to mobile phone EMR. Continuous exposure showed the highest percentage of fragmentation in a timedependant manner [Table-3]. The damage effect of EMR on DNA had been reported in pervious several studies [37-40]. This fragmentation could be due to long exposure to EMR that leads to intracellular membrane vacuolation with lysosomal leakage of different DNases leading to DNA damage [37]. A number of in vivo experiments have found EMR exposure can cause cell damage and reactive oxygen species (ROS) production $[41,42]$, besides, the chronic exposure to EMR induced decreasing in total antioxidant enzyme capacity leading to accumulation of ROS. The leakage of ROS from damaged peroxisomes and damaged mitochondrial membranes leading to DNA damage [40]. Campisim, et al [43] reported that, increases in ROS production and DNA fragmentation in brain cells after acute exposure to EMR emitted from mobile phone. In contrary, other studies failed to prove any contribution of EMR on cellular DNA damage. Hook, et al [44] found that there was not any significant effect of EMR on T lymphoblastoid cells, EMR neither affected the reverse mutation frequency nor accelerated DNA degradation [45]. Others had previously proved that $2450 \mathrm{MHz}$ irradiation does not appear to cause DNA damage in cultured mammalian cells [46].

\section{Conclusion}

In conclusion although there is a still debate among the scientific community regarding the harmful effect of mobile cell phone use, the obtained data warrant the public about the possible contribution of the emitted ERM in deactivation of tumor suppressor genes (TP53 and BRCA1) in mammalian rat model with possible effect in human subject, the fact that needs more care in the use of such facilities, especially among young generation.

Conflicts of Interest : None declared. 


\section{References}

[1] International Telecommunication Union (2011) The world in 2011: ICT facts and figures.

[2] Nittby H., Brun A., Eberheardt J., Malmgren L., Persson B.R.R., Salford L.G. (2009) Pathophysiology, 16(2-3), pp 103-112.

[3] El-Sayed A., Badr H.S., Yahia R., Salem S., Kandil A. (2011) African Journal of Biotechnology, 10(26), 19670-19680.

[4] Khalil A., Alshamali A., Gagaa M.H. (2011) World Academy of Science, Engineering and Technology, 76, 657-662.

[5] Agarwal A., Desai N.R., Makker K., Varghese A., Mouradi R., Sabanegh E. (2009) Fertil. Steril., 92, 1318-1325.

[6] Kumar S., Kesari K.K., Behari J. (2010) Indian J. Exp. Biol., 48, 586-592.

[7] Heynick L.N., Merritt J.H. (2003) Bioelectromagnetics, 24, S174 $-186$.

[8] Bormusov E., Andley U.P., Sharon N., Schachter L., Lahav A., Dovrat A. (2008) The Open Ophthalmology Journal, 2, 102-106.

[9] Xu S., Chen G., Chen C., Sun C., Zhang D., Murbach M., Kuster N., Zeng Q., Xu Z. (2013) PLoS ONE, 8(1), e54906.

[10]Hardell L., Mild K.H., Johansson B. (2003) Arch. Environ. Occup., H58, 380-382.

[11]Phillips J.L., Singhb N.P., Laib H. (2009) Pathophysiology, 16, 79-88.

[12]Levitt N., Hickson I. (2002) Trends in Molecular Medicine, 8(4), 179-186.

[13]Hanahan D., Weinberg R.A. (2011) Cell, 144(5), 646-674.

[14]Hirohashis S., Kanai K. (2003) Cancer Sci., 94(7) 575-581.

[15]Levine A.J., Moman J. and Finley C.A. (1991) Nature, 351, 453456.

[16]Chiaretti S., Brugnoletti F., Tavolaro S., Bonina S., Paoloni F., Marinelli M., Patten N. (2013) Haematologica, 98(5), e59-e61.

[17]Bai L., Zhu W. (2006) Journal of Cancer Molecules, 2(4), 141153.

[18]Deng C.X., Wang H.R. (2003) Human Molecular Genetics, 12 (1), R113-R123.

[19]El Gezeery A., Mahmoud N., Moustafa A., Mahrous H., Mahmoud H., abd el-menam N. (2008) Turkish J. Cancer, 167 38(4), 167-174.

[20]Deng C.X. (2002) Environmental and Molecular Mutagenesis, 39, $171-177$.

[21]Hartman A.R., Ford M.J. (2003) J. Mol. Med., 81, 700-707.

[22]Jiang J., Yang E.S., Jiang G. (2011) Cancer Res., 71, 55465557.

[23] Institute of Laboratory Animal Resources (1995) Guide for the care and use of laboratory animals, Committee on care and use of laboratory animals, NRC, 83.

[24]Parborell F., Pecci A., Gonzalez O., Vitale A., Tesone M. (2002) Biology of Reproduction, 67, 481-486.

[25]Chen K.S., Shepel L., Haag J., Heil G., Gould M. (1996) Carcinogenesis, 17, 1561-1566.

[26]Yassaee R.V., Zeinali S., Harirchi I., Jarvandi S., Mohagheghi M.A., Hornby D.P., Dalton A. (2002) Breast Cancer Research, 4 (4), R6.
[27]Gouda E., Elbehairy A., Ghoneim M. (2008) Zeitschrift für Naturforschung, 63(11), 857.

[28]Diab K., ELmakawy A.I., Abd-Elmoneim M.O., Sharaf H.A. (2012) J. Cytol. Histol., 3(5).

[29]Ahlbom A., Bridges J., De Seze R., Hillert L., Juutilainen J., Mattsson M.O., Neubauer G., Schuz J. (2008) Toxicology, 246 (2-3), 248-250.

[30]Hardell L., Carlberg M. (2009) Int. J. Oncol., 35(1), 5-17.

[31]Lopez-Martin E., Bregains J., Relova-Quinteiro J.L., CadarsoSuarez C., Jorge-Barreiro F.J., Ares-Pena F.J. (2009) J. Neurosci. Res., 87(6), 1484-1499.

[32]Nylund R., Leszezynski D. (2006) Proteomics, 6, 4769-4780.

[33]Karien A., Heinavaara R., Nylund R., Leszczynski D. (2008) BMC Genomics, 9(1), 77.

[34]Hung T., Lee M., Oh E., Zhang T., Seo J., Park W. (2008) Int. J. Radiat. Biol., 4(11), 909-915.

[35]Somasundaram K. (2003) J. Cell Biochem., 88, 1084-1091.

[36]Suen T.C., Goss P.E. (1999) J. of Biological Chemistry, 274 (44), 31297-31304.

[37]Goldsworthy A. (2007) The Biological Effects of Weak Electromagnetic Fields.

[38]Desai N.R., Kavindra K., Agarwal A. (2009) Reprod. Biol. Endocrinol., 7(14), 114-122.

[39]Gandhi G. and Anita (2011) International Journal of Basic and Applied Medical Sciences, 1(1), 87-103.

[40]Shahin S., Singh V.P., Shukla R.K., Dhawan A., Gangwar R.K., Singh S.P., Chaturvedi C.M. (2013) Biochem. Biotechnol., 169(5), 1727-1751.

[41]Oral B., Guney M., Ozguner F., Karahan N., Mungan T., Comlekci S., Cesur G. (2006) Adv. Ther., 23(6), 957-973.

[42]Panagopoulos D.J. (2007) Mutat. Res., 626, 69-78.

[43]Campisim A., Gulino M., Acquavivam R., Bellia P., Raciti G., Grasso R., Musumeci F., Vanella A., Triglia A. (2010) Neurosci. Lett., 473, 52-55

[44]Hook G.J., Zhang P., Lagroye I., Li L., Higashikubo R., Moros E.G., Straube W.L., Pickard W.F., Baty J.D., Roti J.L. (2004) Radiation Research, 161(2), 193-200.

[45]Chang S.K., Choi J.S., Gil H.W., Yang J.O., Lee E.Y., Jeon Y.S., Lee Z.W., Lee M., Hong M.Y., Ho Son T., Hong S.Y. (2005) European Journal of Cancer Prevention, 14(2), 175-179.

[46]Malyapa R.S., Ahern E.W., Straube W.L., Moros E.G., Pickard W.F., Roti J.L. (1997) Radiation Research, 148(6), 618-627. 